\title{
Two-Center Evaluation of Disinfectant Efficacy against Ebola Virus in Clinical and Laboratory Matrices
}

\author{
Sophie J. Smither, Lin Eastaugh, \\ Claire Marie Filone, Denise Freeburger, \\ Artemas Herzog, M. Stephen Lever, \\ David M. Miller, Dana Mitzel, James W. Noah, \\ Mary S. Reddick-Elick, Amy Reese, \\ Michael Schuit, Carly B. Wlazlowski, \\ Michael Hevey, Victoria Wahl-Jensen
}

Ebola virus (EBOV) in body fluids poses risk for virus transmission. However, there are limited experimental data for such matrices on the disinfectant efficacy against EBOV. We evaluated the effectiveness of disinfectants against EBOV in blood on surfaces. Only $5 \%$ peracetic acid consistently reduced EBOV titers in dried blood to the assay limit of quantification.

$\mathrm{E}$ ffective disinfection of Ebola virus (EBOV) in body fluids is critical for emergency response to outbreaks. However, for such fluids, data are scarce for disinfectant efficacy. This information is essential for informed disinfection processes, environmental decontamination, waste disposal practices, and safety practices for healthcare workers and public health responders (1). We investigated the efficacy of disinfectants against EBOV spiked into cell culture medium and whole blood.

\section{The Study}

Six disinfectants were tested: Purrell Advanced (GOJO Industries, Akron, OH, USA) $30 \mu \mathrm{L}$; Steriplex SD (sBiomed LLC, Orem, UT, USA) $100 \mu \mathrm{L}$; Micro-Chem Plus (National Chemical Laboratories, Inc., Winona, MN, USA) 30 $\mu \mathrm{L}$; Micro-Chem Plus $100 \mu \mathrm{L}$; bleach (Clorox, Oakland, CA, USA) $30 \mu \mathrm{L}$ and $100 \mu \mathrm{L}$; acidified bleach $100 \mu \mathrm{L}$; and peracetic acid (Sigma-Aldrich, St. Louis, MO, US) $100 \mu \mathrm{L}$. The 2 most effective disinfectants were evaluated at 2 laboratories: the National Biodefense Analysis and

Author affiliations: Defence Science and Technology Laboratory,

Porton Down, UK (S.J. Smither, L. Eastaugh, M.S. Lever);

National Biodefense Analysis and Countermeasures Center,

Frederick, Maryland, USA (C.M. Filone, D. Freeburger, D.M. Miller,

D. Mitzel, J.W. Noah, M.S. Reddick-Elick, A. Reese, M. Schuit,

C.B. Wlazlowski, M. Hevey, V. Wahl-Jensen); Censeo Consulting

Group, Seattle, Washington, USA (A. Herzog)

DOI: https://doi.org/10.3201/eid2401.170504
Countermeasures Center (NBACC; Frederick, MD, USA); and the Defence Science and Technology Laboratory (DSTL; Porton Down, UK). Because of local regulations and operating procedures, some methods were modified between the laboratories (Table 1).

At NBACC, material was prepared as follows. Passage 1 of Ebola virus H.sapiens-tc/GIN/2014/Makona-C05 virus (Rocky Mountain Laboratory, National Institutes of Health, Hamilton, MT, USA) was used to generate passage 2 virus stock in Vero E6 cells (Table 1). All work with viable EBOV was performed in Biosafety Level 4 laboratories.

At DSTL, material was prepared as follows. Passage 4 of Ebola virus H.sapiens-wt/GIN/2014/Makona-C07 virus (Public Health England, London, UK) was passed twice in Vero E6 cells, creating passage 6 material. All work with viable EBOV was performed in Biosafety Level 4 laboratories.

Stainless steel and aluminum coupons $\left(\approx 22 \mathrm{~mm}^{2}\right)$ were sterilized before use. Test matrices included cell culture medium, human whole blood (NBACC), or rat whole blood (DSTL).

To test disinfectants, we spiked Ebola/Mak 1:10 into a test matrix and then deposited it onto coupons. We disinfected coupons immediately (wet) or kept them at ambient conditions until dry by visual examination (2) and then disinfected (dry). Disinfectants were applied for various contact times (Table 1). We performed no surface agitation or mixing before sample recovery, per the method of the American Society for Testing Materials International (West Conshohocken, PA, USA) (2). We performed neutralization by submersion into cell culture medium and vortexing according to recommendations of ASTM International $(2,3)$ (Table 1). Viable virus was measured in samples as described $(4,5)$. We performed statistical analysis of sample results (online Technical Appendix, https://wwwnc.cdc.gov/EID/article/24/1/170504-Techapp1.pdf).

All disinfectants tested reduced virus titer to the asssay lower limit of quantification (LLOQ) of the assay when evaluated with EBOV/Mak deposited on surfaces in cell culture medium (Table 2). However, only $5 \%$ peracetic acid consistently reduced the titer of EBOV/Mak in dried human blood to the assay LLOQ. These data collectively indicate that surface-dried whole blood provides a more protective matrix for EBOV/Mak than does surface-dried cell culture medium. 
Because EBOV/Mak in dried blood resists complete bleach disinfection $(0.5 \%$ or $1.0 \%$ sodium hypochlorite $)$ but this method is commonly used in outbreak and health- care settings (6), we sought independent confirmation. We shared protocols and surface coupons with DSTL, who verified that $\mathrm{EBOV} / \mathrm{Mak}$ dried in cell culture medium was

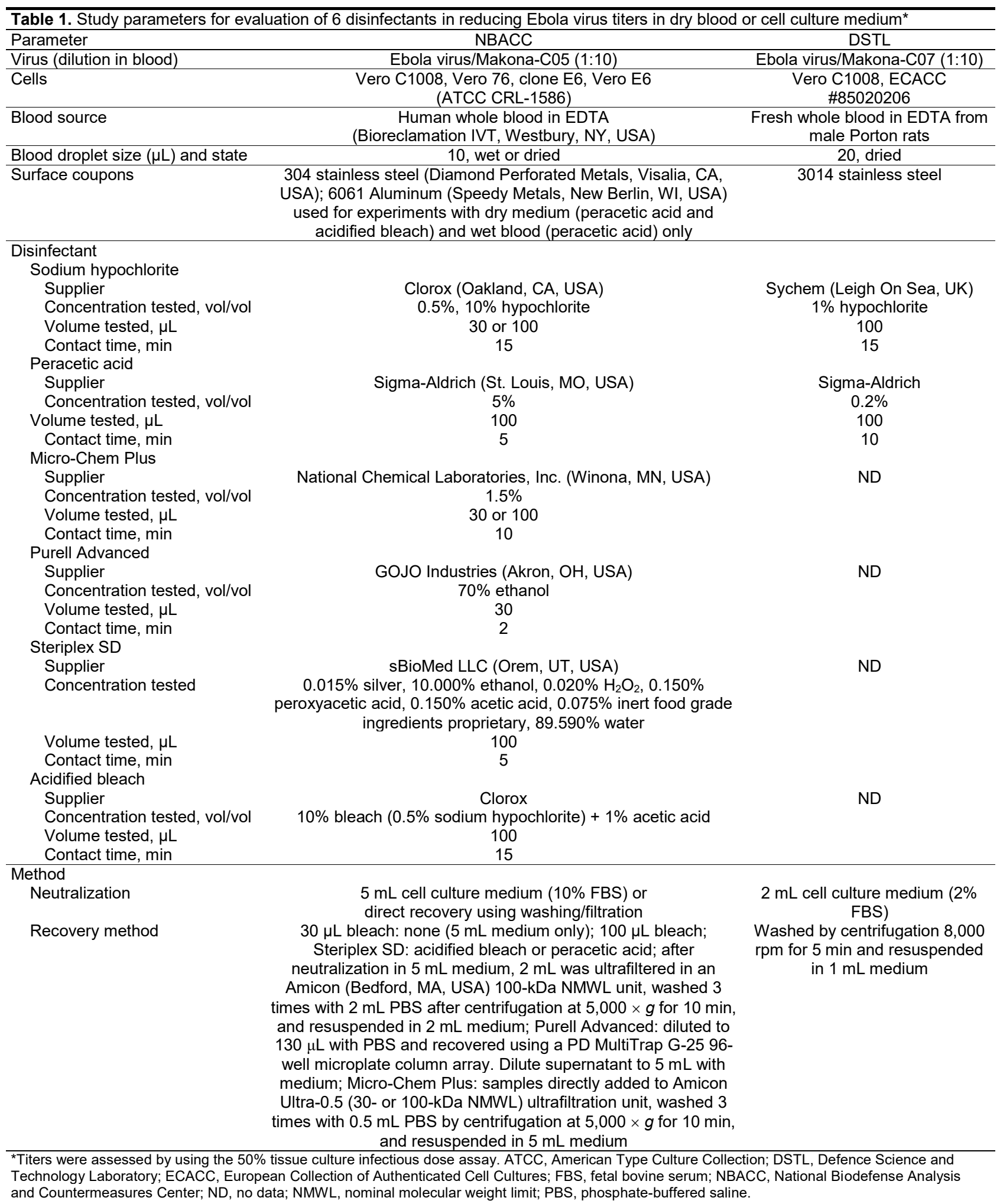



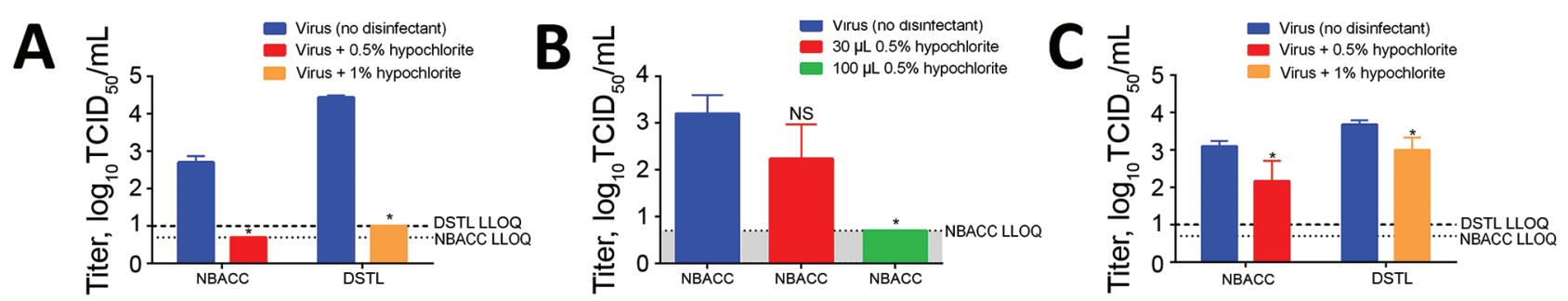

Figure 1. Effect of common bleach disinfection of Ebola virus in A) dried cell culture medium, B) wet blood, and C) dried blood. Coupons were spotted with Ebola virus/Makona (EBOV/Mak). Bleach solutions ( $0.5 \%$ or $1.0 \%$ hypochlorite) were effective in reducing the titer of EBOV/Mak to the assay LLOQ in dried cell culture medium or wet blood. Incomplete disinfection was observed when virus was suspended in blood and dried for $1 \mathrm{~h}$ before disinfection. Data were confirmed for dried cell culture medium and dried blood studies at an independent laboratory (DSTL). Error bars indicate SD. *Significant difference $(p<0.05)$ between control and disinfected samples. DSTL, Defence Science and Technology Laboratory; LLOQ, lower limit of quantification; NBACC, National Biodefense Analysis and Countermeasures Center.

highly susceptible to disinfection with sodium hypochlorite (Figure 1, panel A). However, when dried blood samples were treated with $0.5 \%$ or $1.0 \%$ sodium hypochlorite, viral titer reductions of only $88.3 \%$ and $79.0 \%$, respectively, were observed (Figure 1, panel C). Furthermore, viable virus was recovered from all samples, confirming that dried blood represents a challenging matrix for disinfection of EBOV/Mak.

We also measured effectiveness of disinfection with $10 \%$ bleach against EBOV in wet blood on coupons. When we suspended EBOV/Mak in wet blood, $10 \%$ bleach was either $89.2 \%(30 \mu \mathrm{L})$ or $99.7 \%(100 \mu \mathrm{L})$ effective in reducing viral titers, depending on the volume (and consequently the final concentrations) of bleach used. Application of 100 $\mu \mathrm{L}$ of bleach to wet blood samples resulted in a significant reduction in viral titer to the LLOQ of the assay (Figure 1, panel B), suggesting that wet blood is less challenging to disinfection than dried blood.

Of the 6 disinfectants we evaluated, only $5 \%$ peracetic acid was efficacious in disinfecting dried blood samples containing EBOV/Mak (Table 2). Concentrations of 5\% peracetic acid also reduced viral titers to the LLOQ of the microtitration assay when virus was in either dried cell culture medium (Figure 2, panel A) or wet blood (Figure 2, panel B). Although studies at NBACC showed complete inactivation of EBOV/Mak in dried blood by $5 \%$ peracetic acid, complementary studies at DSTL showed that use of a lower concentration $(0.2 \%)$ of peracetic acid resulted in a $94.9 \%$ reduction in viral titers in samples with viable virus still present (Figure 2, panel C). Taken together, these results suggest that there might be a concentration-dependent reduction in viral titers in dried blood when peracetic acid is used for disinfection.

\section{Conclusions}

The purpose of this study was to test products for disinfection of EBOV in a relevant clinical matrix. Previous studies showed that filoviruses remain viable in blood for extended periods $(5,7,8)$. Therefore, it was imperative to identify efficacious disinfectants for this matrix. Our results indicate that although bleach, Purell Advanced, and Micro-Chem Plus effectively inactivated EBOV in cell culture medium and wet blood, they were less effective in dried blood.

Only $5 \%$ peracetic acid consistently reduced EBOV titers in dried blood to the assay LLOQ. Peracetic acid is a strong oxidant and broad-spectrum disinfectant commonly used in disinfection of a variety of pathogens in waste
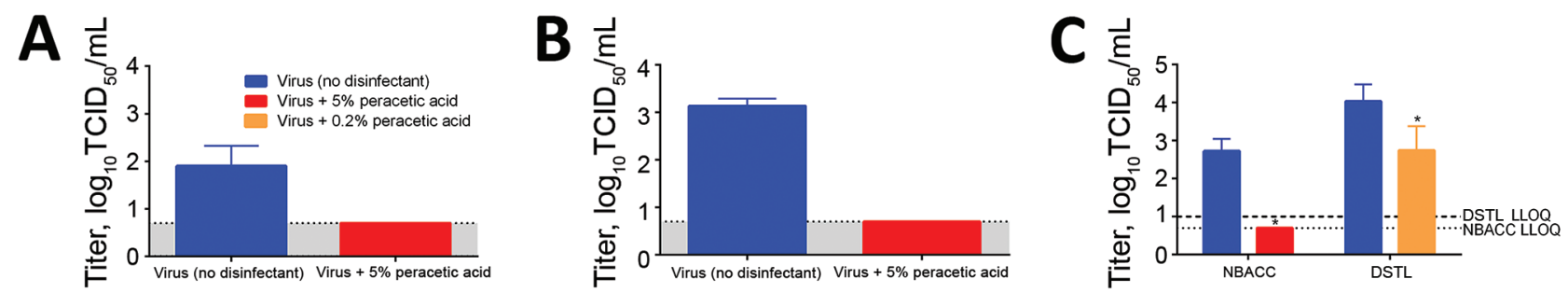

Figure 2. Effect of $5 \%$ peracetic acid disinfection of Ebola virus in 3 different matrices. Coupons were spotted with Ebola virus/Makona (EBOV/Mak) in cell culture medium (A) or blood (B, C). Peracetic acid was effective in reducing the titer of EBOV/Mak to the assay LLOQ in dried cell culture medium or wet blood. Although complete disinfection was observed when virus was suspended in blood and dried for $1 \mathrm{~h}$ before disinfection with $5 \%$ peracetic acid (NBACC), incomplete disinfection was observed with $0.2 \%$ peracetic acid (DSTL). Error bars indicate SD. *Significant difference $(p<0.05)$ between control and disinfected samples. DSTL, Defence Science and Technology Laboratory; LLOQ, lower limit of quantification; NBACC, National Biodefense Analysis and Countermeasures Center. 
Table 2. NBACC studies of evaluation of 6 disinfectants for reducing Ebola virus titers in dry blood or cell culture medium*

\begin{tabular}{|c|c|c|c|c|c|c|c|c|}
\hline \multirow[b]{2}{*}{$\begin{array}{l}\text { Disinfectant and } \\
\text { volume, } \mu \mathrm{L}\end{array}$} & \multicolumn{4}{|c|}{ Dried blood } & \multicolumn{4}{|c|}{ Dried cell culture medium } \\
\hline & $\begin{array}{c}\text { Mean } \log _{10} \\
\text { TCID }_{50}(\mathrm{SD}) \\
\text { disinfected }\end{array}$ & $\begin{array}{c}\text { Mean } \log _{10} \\
\text { TCID }_{50}(\mathrm{SD}) \\
\text { control }\end{array}$ & $\begin{array}{c}\log \\
\text { difference }\end{array}$ & $\begin{array}{l}t \text {-test } \mathrm{p} \\
\text { value }\end{array}$ & $\begin{array}{c}\text { Mean } \log _{10} \\
\text { TCID }_{50}(\mathrm{SD}) \\
\text { disinfected }\end{array}$ & $\begin{array}{c}\text { Mean } \log _{10} \\
\text { TCID }_{50}(\mathrm{SD}) \\
\text { control }\end{array}$ & $\begin{array}{c}\log \\
\text { difference }\end{array}$ & $\begin{array}{l}t \text {-test } p \\
\text { value }\end{array}$ \\
\hline Purell Advanced, 30 & $3.1(0.2)$ & $2.6(0.3)$ & $<0$ & $9.5 \times 10^{-1}$ & $0.7(0)$ & $2.4(0.3)$ & 1.7 & $5.6 \times 10^{-3}$ \\
\hline Steriplex SD, 100 & $2.4(0.2)$ & $3.0(0.2)$ & 0.6 & $8.8 \times 10^{-3}$ & $0.7(0)$ & $3.3(0.2)$ & 2.6 & $5.9 \times 10^{-4}$ \\
\hline Micro-Chem Plus, 30 & $2.8(0.5)$ & $3.4(0.5)$ & 0.6 & $4.9 \times 10^{-2}$ & $0.7(0)$ & $1.5(0.2)$ & 0.8 & $3.6 \times 10^{-5}$ \\
\hline Micro-Chem Plus, 100 & $1.5(0.1)$ & $2.9(0.2)$ & 1.4 & $1.4 \times 10^{-4}$ & ND & ND & ND & ND \\
\hline Bleach, 30 & $2.2(0.5)$ & $3.1(0.1)$ & 0.9 & $1.1 \times 10^{-3}$ & $0.7(0)$ & $2.7(0.2)$ & 2.0 & $1.3 \times 10^{-3}$ \\
\hline Acidified bleach, 100 & $1.7(0.3)$ & $2.7(0.3)$ & 1.1 & $5.9 \times 10^{-3}$ & $0.7(0)$ & $2.6(0.2)$ & 1.9 & $2.0 \times 10^{-3}$ \\
\hline Peracetic acid, 100 & $0.7(0)$ & $2.7(0.3)$ & 2.0 & $4.3 \times 10^{-3}$ & $0.7(0)$ & $1.9(0.4)$ & 1.2 & $7.8 \times 10^{-2}$ \\
\hline
\end{tabular}

water because of its relative ease of implementation, broad-spectrum activity in the presence of heterogeneous organic matter, small $\mathrm{pH}$ dependence, short contact time, and lack of harmful decomposition products (9). Although peracetic acid has been reported to be an effective disinfectant against EBOV (10), use of peracetic acid for EBOV disinfection in clinical fluids has not been specifically documented.

Organic matter in clinical fluids can reduce the virucidal activity of disinfectants by a chemical reaction between the disinfectant and the organic matter, which leaves less active disinfectant available for virus inactivation. In particular, chlorine disinfectants are prone to inactivation by reactions with organic matter $(11,12)$. Alternatively, organic matter can prevent inactivation of viruses by acting as a physical barrier $(13,14)$. Our results suggest that under the conditions tested, dried blood inhibits effective disinfection of EBOV and might provide a protective layer of matrix not completely dissolved in disinfectant, thereby shielding virus from inactivation.

This study used the American Society for Testing Materials International standard (2) for testing of disinfectants on carriers and represents a worst-case scenario. However, it is possible that precleaning, agitation, or mixing would aid in the disinfection process. Additional testing is required to confirm this possibility.

In summary, our results show the difficulty in disinfecting surfaces contaminated with EBOV in dried blood. Although all disinfectants tested were effective against dried cell culture medium containing EBOV, only 5\% peracetic acid reduced dried blood virus titers to undetectable levels. These findings can be used to support public health efforts, risk assessment development, remediation decisions, and response and preparedness procedures for future outbreaks of infection with EBOV.

\section{Acknowledgments}

NBACC thanks S.E. Miller, H. Cronin, T. Jenkins, S. Rippeon, S.A. Miller, M. Seaton, and D. Dawson for technical support; Devon R. Byrd for the suggestion and intellectual contributions regarding use of acidified bleach and peracetic acid as disinfectants; and persons who participated in the interagency design and critique of this study from the Centers for Disease Control and Prevention, US Defense Advanced Research Projects Agency, US Department of Homeland Security, US Department of Defense, US Environmental Protection Agency, US Federal Bureau of Investigation, US Department of Health and Human Services, US Office of the Director of National Intelligence, and the Executive Office of the President. DSTL thanks S. Ngugi, L. O'Brien, A. Phelps, and J. Steward for providing practical assistance; R. Beedham, L. Colf, and S. Perkins for providing assistance and support; and the European Mobile Laboratory and Ministry of Health of Guinea for supplying virus to DSTL.

This study was supported by contract no. HSHQDC-15-C-00064 from the Department of Homeland Security Science and Technology Directorate for operation and management of NBACC, a federally funded research and development center; and Task CB-AT-4186 from the Combating Terrorism Technical Support Office/Technical Support Working Group. DSTL was supported by the UK Ministry of Defence.

Content includes material subject to Crown copyright (2017) to DSTL. This material is licensed under the terms of the Open Government License except where otherwise stated. To view this license, visit http://www.nationalarchives.gov.uk/doc/ open-government-licence/version/3; write to the Information Policy Team, The National Archives, Kew, London TW9 4DU, UK, or email: psi@nationalarchives.gsi.gov.uk.

Dr. Smither is a senior virologist at the Defence Science and Technology Laboratory, Porton Down, Salisbury, UK. Her primary research interests are high-containment microbiology and aerobiology, aerosol hazards of filoviruses, different virus inactivation and disinfection methods, and development of animal models of filovirus infection.

\section{References}

1. Reeve M, Altevogt B; Board on Health Sciences Policy. Board on Global Health; Board on Population Health and Public Health Practice; Board on Life Sciences; Institute of Medicine; National Research Council, 23014. Research priorities to inform public health and medical practice for Ebola virus disease: workshop in brief. The National Academies Press [cited 2017 Nov 21]. http://www.iom.edu/ebolatransmissionresearch 
2. American Society for Testing Materials International. Standard quantitative disk carrier test method for determining bactericidal, virucidal, fungicidal, mycobactericidal, and sporicidal activities of liquid chemical germicides. Environmental toxicology standards E2197-11, 2011 [cited 2017 Nov 21]. https://www.astm.org/Standards/E2197.htm

3. American Society for Testing Materials International. Standard practice for use of gel filtration columns for cytotoxicity reduction and neutralization. Environmental toxicology standards E1482-12, 2012 [cited 2017 Nov 21]. https://www.astm.org/Standards/E1482.htm

4. Reed LJ, Muench H. A simple method of estimating fifty percent endpoints. Am J Hyg. 1938;27:493-7.

5. Schuit M, Miller DM, Reddick-Elick MS, Wlazlowski CB, Filone CM, Herzog A, et al. Differences in the comparative stability of Ebola virus Makona-C05 and Yambuku-Mayinga in blood. PLoS One. 2016;11:e0148476. http://dx.doi.org/10.1371/ journal.pone. 0148476

6. Centers for Disease Control and Prevention. For general healthcare settings in West Africa: how to prepare and use chlorine solutions, 2015 [cited 2017 Nov 21]. https://www.cdc.gov/vhf/ebola/hcp/ mixing-chlorine-solutions.html

7. Fischer R, Judson S, Miazgowicz K, Bushmaker T, Prescott J, Munster VJ. Ebola virus stability on surfaces and in fluids in simulated outbreak environments. Emerg Infect Dis. 2015;21:1243-6. http://dx.doi.org/10.3201/eid2107.150253

8. Piercy TJ, Smither SJ, Steward JA, Eastaugh L, Lever MS The survival of filoviruses in liquids, on solid substrates and in a dynamic aerosol. J Appl Microbiol. 2010;109: 1531-9.

9. Kitis M. Disinfection of wastewater with peracetic acid: a review. Environ Int. 2004;30:47-55. http://dx.doi.org/10.1016/ S0160-4120(03)00147-8

10. Kiley MP, Bowen ET, Eddy GA, Isaäcson M, Johnson KM, McCormick JB, et al. Filoviridae: a taxonomic home for Marburg and Ebola viruses? Intervirology. 1982;18:24-32. http://dx.doi.org/10.1159/000149300

11. Fukuzaki S. Mechanisms of actions of sodium hypochlorite in cleaning and disinfection processes. Biocontrol Sci. 2006; 11:147-57. http://dx.doi.org/10.4265/bio.11.147

12. Rutala WA, Weber DJ; Healthcare Infection Control Practices Advisory Committee (HICPAC). 2008. Guideline for disinfection and sterilization in healthcare facilities, 2008 [cited 2015 Oct 12]. http://www.cdc.gov/hicpac/pdf/guidelines/Disinfection Nov_2008.pdf

13. Lewis DL, Arens M. Resistance of microorganisms to disinfection in dental and medical devices. Nat Med. 1995;1:956-8. http://dx.doi.org/10.1038/nm0995-956

14. Muscarella LF. Sterilizing dental equipment. Nat Med. 1995;1:1223-5. http://dx.doi.org/10.I038/nm1295-1223b

Address for correspondence: Victoria Wahl-Jensen, National Biological Threat Characterization Center, 8300 Research Plaza, Frederick, MD, 21702-4421, USA; email: victoria.wahl@nbacc.dhs.gov

\section{EID SPOTLIGHT TOPIC}

Ebola, previously known as Ebola hemorrhagic fever, is a rare and deadly disease caused by infection with one of the Ebola virus strains. Ebola can cause disease in humans and nonhuman primates (monkeys, gorillas, and chimpanzees).

Ebola is caused by infection with a virus of the family Filoviridae, genus Ebolavirus. There are five identified Ebola virus species, four of
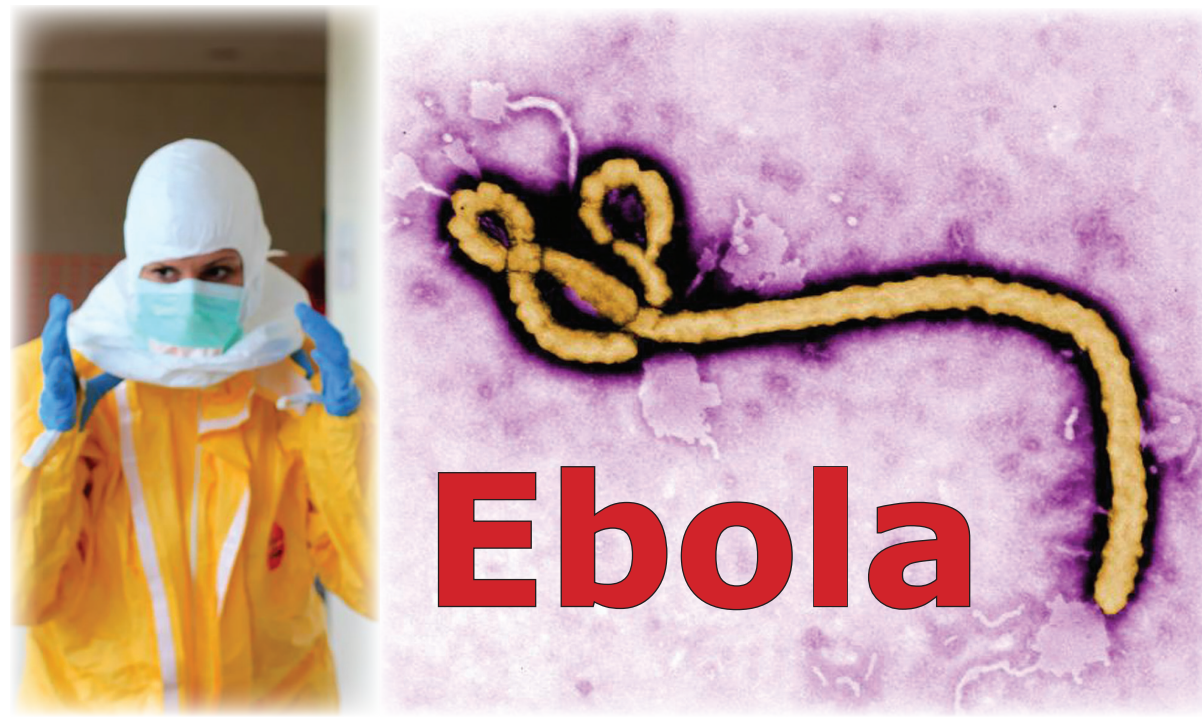
which are known to cause disease in humans. Ebola viruses are found in several African countries; they were first discovered in 1976 near the Ebola River in what is now the Democratic Republic of the Congo. Before the current outbreak, Ebola had appeared sporadically in Africa.

The natural reservoir host of Ebola virus remains unknown. However, on the basis of evidence and the nature of similar viruses, researchers believe that the virus is animal-borne and that bats are the most likely reservoir. Four of the five virus strains occur in an animal host native to Africa.

\section{EMERGING INFECTIOUS DISEASES}

